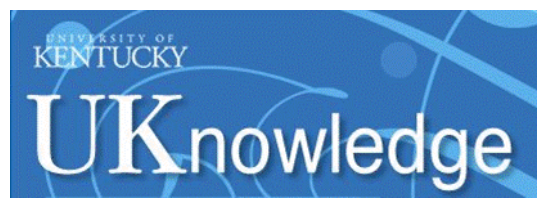

University of Kentucky

UKnowledge

Educational, School, and Counseling

Psychology Faculty Publications

Educational, School, and Counseling

Psychology

$12-11-2020$

\title{
The Impact of Standards-Based Learning: Tracking High School Students' Transition to the University
}

Thomas R. Guskey

University of Kentucky, GUSKEY@UKY.EDU

Matt Townsley

University of Northern lowa

Thomas M. Buckmiller

Drake University

Follow this and additional works at: https://uknowledge.uky.edu/edp_facpub

Part of the Educational Assessment, Evaluation, and Research Commons

Right click to open a feedback form in a new tab to let us know how this document benefits you.

\section{Repository Citation}

Guskey, Thomas R.; Townsley, Matt; and Buckmiller, Thomas M., "The Impact of Standards-Based Learning: Tracking High School Students' Transition to the University" (2020). Educational, School, and Counseling Psychology Faculty Publications. 42.

https://uknowledge.uky.edu/edp_facpub/42

This Article is brought to you for free and open access by the Educational, School, and Counseling Psychology at UKnowledge. It has been accepted for inclusion in Educational, School, and Counseling Psychology Faculty Publications by an authorized administrator of UKnowledge. For more information, please contact UKnowledge@lsv.uky.edu. 


\section{The Impact of Standards-Based Learning: Tracking High School Students' Transition to the University}

\section{Digital Object Identifier (DOI)}

https://doi.org/10.1177/0192636520975862

Notes/Citation Information

Published in NASSP Bulletin, v. 104, issue 4.

(c) 2020 SAGE Publications

Under SAGE's Green Open Access policy, the Accepted Version of the article may be posted in the author's institutional repository and reuse is restricted to non-commercial and no derivative uses.

The document available for download is the authors' post-peer-review final draft of the article. 


\title{
The Impact of Standards-Based Learning:
}

\section{Tracking High School Students' Transition to the University}

\author{
Thomas R. Guskey \\ Professor Emeritus, University of Kentucky \\ Email: guskey@uky.edu \\ Phone: 859-221-0077 \\ Address: 2108 Shelton Road, Lexington, KY 40515
}

\author{
Matt Townsley \\ Assistant Professor, University of Northern Iowa
}

Email: matt.townsley@uni.edu

Phone: 319-273-3564

Address: 601D Schindler Education Center, Cedar Falls, IA 50614

\author{
Thomas M. Buckmiller \\ Associate Professor, Drake University \\ Email: thomas.buckmiller@drake.edu \\ Phone: 515-271-4989
}

Address: 2507 University Ave., Collier-Scripps Hall, Des Moines, IA 50311

Guskey, T. R., Townsley, M., \& Buckmiller, T. M. (2020). The impact of standards-based learning: Tracking high school students transition to the university.

$$
\text { NASSP Bulletin, 104(4) 257-269. }
$$




\title{
The Impact of Standards-Based Learning: Tracking High School Students' Transition to the University
}

\begin{abstract}
This study sought to determine if the implementation of standards-based learning (SBL) in high schools affects students' transition to learning in university courses. Surveys and interviews with 13 student who had graduated from high schools implementing SBL and who had completed their first academic semester at a mid-size, private, Midwest university revealed no detrimental effects. The most frequently mentioned transition difficulties related to social issues and time management. Implications for implementing high school grading reforms are discussed.
\end{abstract}

Key words: Grading, Standards-based learning, College transition. 


\section{The Impact of Standards-Based Learning: Tracking High School Students' Transition to the University}

Changes in schooling brought about by the onset of the corona-virus pandemic compelled educators to rethink many aspects of our education system, especially the way we grade and report student learning. Colleges and universities were the first to enact major changes in their grading systems. Recognizing the inequities involved in the immediate transition to online learning and the difficulties professors and instructors would have in distinguishing multiple levels of student achievement, many colleges and universities temporarily suspended the use of traditional letter grades and instituted satisfactory/incomplete grading systems (Farrington, 2020; Svyrluga, 2020). Elementary and secondary school educators quickly followed, implementing a variety of different grading plans in hopes of making the process easier for teachers as well as fairer and more equitable for students (Doyne \& Gonchar, 2020; St. George, 2020).

Forced to make these significant changes in grading policies and practices prompted many K-12 educators to consider alternative grading models, especially those associated with standards-based grading (SBG). Although definitions of SBG vary, Welch (2019) suggests the model differs from previous grading practices in three important ways (see Guskey \& Bailey, 2001, 2010). First, teachers report student performance based upon key grade level or course standards rather than single content-area grades. Second, student achievement is communicated using a limited number of performance categories such as Beginning, Progressing, Proficient, and Exemplary. Third, academic grades are reported separately from information related to noncognitive factors such as behavior, effort, homework completion, and class participation (Guskey, 1994, 1996). 
Despite its intuitive appeal among educators, parent groups in some school districts have expressed concerns about SBG. In particular, parents worry that implementing SBG policies and practices may foster "bad habits" that will be detrimental to students' success when they matriculate to college or university learning environments (Frankin et al., 2016; Murray, 2019; Tellers, 2017). One such bad habit stems from the common practice associated with many SBG programs of allowing students multiple opportunities to demonstrate their achievement of course learning goals or standards (Knight \& Cooper, 2019; O'Connor, 2018; Townsley et al., 2019). Some parents believe this practice diminishes students' motivation to prepare for initial assessments. They further contend it leaves students ill-prepared for college and university courses where students will be allowed only one opportunity to demonstrate what they have learned (Bowen, 2018; Frankin et al., 2016; Idzerda, 2018). Advocates of SBG counter that providing students with multiple opportunities to reassess offers tangible benefits to learners of all abilities (Dueck, 2011), better prepares students for real life (Wormeli, 2011) and better communicates what students have learned rather than simply their ability to accumulate points (O'Connor, 2017). Still, in the absence of strong evidence confirming these benefits, many parents remain unconvinced.

To provide evidence on the cogency of these concerns, we decided to study this phenomenon by bringing students' voice into the conversation. Based on the suggestions for future research offered by Townsley (2019), we designed an exploratory investigation to address several of parents' most common questions about SBG. Specifically, we sought to determine if students believed the implementation of SBG in their high school classes helped or hindered their transition to learning in college or university classrooms. To answer this question, we gathered data from students who graduated from high schools that implemented the principles of 
SBG and who had just completed their first semester of study at a major university. Our goal was to determine what impact experiencing SBG in their high school classes had on these students' transition to a higher education learning environment.

\section{Background}

Most elementary and secondary school teachers consider a variety factors in determining students' grades. These factors include achievement data drawn from students' performance on class assessments, compositions, projects, etc., as well as non-cognitive process factors related to students' behavior, effort, and compliance with class rules (see Guskey \& Link, 2019). Researchers refer to this amalgamation as a "hodgepodge" grade (Brookhart, 1991) that proves extremely difficult to interpret accurately. For example, the high school student who receives a high grade in chemistry may have demonstrated a thorough understanding of chemistry concepts and the ability to apply that understanding in real-world contexts. But it also could be that the student simply put forth exceptional effort, turned in all homework assignments on time, and prepared lab reports that were neat and well organized. To accurately communicate meaningful information about students' performance in school, these achievement and non-cognitive factors must be reported separately (Guskey, 2020).

Researchers have long been interested in the specific non-cognitive factors that most contribute to students' success in post-secondary education (Sommerfeld, 2011; Ting, 1998). For example, the Non-Cognitive Questionnaire (NCQ), developed by Tracey and Sedlacek (1984), measures eight non-cognitive factors believed to be important to students' success in college and university classrooms, including: "positive self-concept, realistic self-appraisal, understanding and coping with racism, preference for long range goals, availability of a strong support person, 
successful leadership experience, demonstrated community service, and acquired knowledge in a field" (p. 171).

The NCQ has been used by researchers for over 20 years to predict success in college. Adebayo (2008), for example, found that high school grade point average combined with the non-cognitive factors of realistic self-appraisal and understanding and coping with racism were the best predictors of first semester college grade-point average among conditionally admitted freshmen. Similarly, studies by Ting (2009) and Ting and Robinson (1998) revealed that a combination of academic and non-cognitive factors significantly improved predictions of students' first and second semester college grade point averages. These investigations showed that leadership experience and community service were particularly helpful predictors of second semester college success for first generation, low income students, whereas community service and SAT math score were the strongest predictors of first semester grade point average among a relatively homogeneous sample of students (Ting, 1998).

Other research has identified additional non-cognitive factors that contribute to postsecondary success. Self-esteem, for example, has been found to be a significant predictor of first semester college success among first generation college students (Aspelmeier et al., 2012). Studies show that parental influence (Leonard, 2013), parents' educational attainment (Li \& McKillup, 2014), and family structure (Reynolds et al., 2012) can be influential as well. Furthermore, students who cope better with stress and adversity tend to have higher first semester college grade-point averages than their less resilient peers (Reynolds \& Weigand, 2010). Hence, both previous academic achievement and non-cognitive factors significantly contribute to students' success in college and university learning environments. 


\section{Our Study}

Our exploratory, mixed methods study sought to determine if the implementation of SBG in high school classes affects students' transition to university learning environments. To address this question, we secured IRB approval and sent an email message to all 750 first-year students enrolled at a private, Midwest university, inviting all those who graduated from high schools that used SBG to participate in our study. The 18 students who replied were sent a survey that asked the extent to which their high school had implemented SBG, two open-ended items about their personal experiences with SBG, and several items regarding student demographic information. Thirteen of the 18 responding students met the minimum criterion for participation, which was that their high school had implemented at least two of the three defining characteristics of SBG.

Our survey asked students to rate the extent to which their high school had implemented practices typically associated with standards-based learning (SBL), which addresses aspects of curriculum, instruction, assessment, and grading (Schimmer et al., 2018). This required adding additional practices to the three defining characteristics of standards-based grading (SBG) noted by Welch (2019). These practices included the alignment of instruction and assessments (Muñoz \& Guskey, 2015; Rinkema \& Williams, 2019), the replacement of percentage grades with categories of student performance in reporting (Guskey, 2013), the provision of multiple opportunities for students to demonstrate proficiency on class assessments, and the elimination of class rank calculations (Guskey, 2014, 2015). Specifically, we asked about the following five characteristics of standards-based learning (SBL):

1. Student performance is based upon key course or grade level standards rather than single content-area grades. 
2. Student achievement is communicated using performance categories rather than percentage grades.

3. Academic grades are reported separately from non-cognitive factors.

4. Students are allowed multiple opportunities to demonstrate proficiency on class assessments.

5. The calculation of graduating seniors' class rank is eliminated.

To determine the degree to which students' high schools had implemented these SBL practices, we classified each student's school on a 17-point scale. Responses to the first four practices were recorded on a Likert scale with the following levels: (1) None of my classes; (2) A few of my classes; (3) Most of my classes; or (4) All of my classes. Responses to the last practice regarding class rank were recorded as either 0 for "No" and 1 for "Yes." Aggregate scores of 15-17 were considered "High Fidelity" SBG schools; scores of 12-14 were considered "Moderate Fidelity," and scores 11 or less were considered "Low Fidelity."

The first of the two open-ended survey items asked students, "Was there anything in particular about your experiences with SBL in high school that was beneficial or detrimental to your transition to the university?" Several responses to this item described negative aspects, mainly related to assessment retake policies and percentage grades. For example, one student said, "I got used to always getting a do-over, whereas in university classes it's almost never that way." However, the majority of responses were complementary of SBL practices in high school. One student remarked, "It taught me to go back and re-learn material I struggled on till I mastered it, rather than taking a test and forgetting about whatever I messed up on.” 
The second of the two open-ended survey items asked students, "What was the most difficult challenge you had in transitioning from high school to college?" The most frequent responses to this item were socially oriented. For example, one student said, "The fear of having a new living routine and meeting new people." Although one response mentioned, "The grading style and how to study for exams," the remaining academic-oriented responses were more focused on time management and amount of work to be submitted. One student noted, "The curricula is much denser, which was quite a difficult transition to adapt to."

In the second phase of the study we asked the 13 participating students to take part in a one-on-one, semi-structured interview. For their participation in the interview, students were offered a \$10 gift card to the university bookstore. Seven of the 13 students volunteered to participate in the interviews, which were conducted during the second academic semester, after students had received their first semester grades and had time to reflect on their first semester experience. Interviews lasted approximately 45 minutes, and no students' names were reported in the results. Table 1 shows a brief description of the students who participated and their responses to the open-ended questions about their first semester experiences at the university and how it compared to their high school years. 
Table1. Study participants

\begin{tabular}{|c|l|l|l|}
\hline Participant & $\begin{array}{c}\text { H.S. } \\
\text { GPA }\end{array}$ & $\begin{array}{c}\text { H.S. SBL } \\
\text { Fidelity }\end{array}$ & Response to open-ended items \\
\hline 1 & 3.76 & Low & $\begin{array}{l}\text { (SBL) taught me to go back and re-learn material I } \\
\text { struggled on till I mastered it rather than taking a test and } \\
\text { forgetting about whatever I messed up on. }\end{array}$ \\
\hline 2 & 3.80 & Moderate & $\begin{array}{l}\text { (SBL) allowed me to really see, in words, how I was doing } \\
\text { on a topic, rather than just being handed a percentage. }\end{array}$ \\
\hline 3 & 4.00 & Low & $\begin{array}{l}\text { Class was structured around trivial and less sophisticated } \\
\text { material and very little emphasis was put on the fact that } \\
\text { further exploration (extension beyond the standards) was } \\
\text { even an option, that I had the possibility to earn a higher } \\
\text { grade. }\end{array}$ \\
\hline 5 & 3.80 & High & $\begin{array}{l}\text { (SBL) didn't prepare me for not being allowed to retake } \\
\text { assessments or be "late" with homework as homework } \\
\text { was not an impact on the final grade. }\end{array}$ \\
\hline 6 & 4.00 & Moderate & $\begin{array}{l}\text { Low } \\
\text { see any way it could have helped me prepare for } \\
\text { university. }\end{array}$ \\
\hline & Moderate & $\begin{array}{l}\text { I got used to always getting a do-over, whereas in } \\
\text { university it's almost never going to be that way. } \\
\text { requirement (was a potential downfall of SBL in high } \\
\text { school). }\end{array}$ \\
\hline & I believe there are plenty of benefits to (SBL). However, it \\
\hline
\end{tabular}

We initially sorted students' responses to the open-ended question using open coding (Strauss \& Corbin, 1990) in order to produce broad categories and identify general patterns. We then used general theme-building strategies to make sense of the categories. This process led to the themes described in the Results below. 


\section{Results}

Analyses of the survey data and interviews with students showed that the high schools from which the students included in our sample graduated are not implementing SBL with high levels of fidelity. However, to the degree SBL was implemented, it does not appear to have detrimental impact on students' transition to higher education. We found no evidence in students' responses to indicate that SBL practices had created hardship or negatively influenced their performance in their college courses.

\section{High schools are not implementing Standards-based learning with fidelity.}

The high schools from which these students graduated were not implementing SBL with high fidelity. Only one of the seven students' descriptions indicated a high degree of fidelity in implementing elements defined as essential by SBL and grading reform advocates (Guskey, 2013, 2014, 2015; Knight \& Cooper, 2019; O’Connor, 2018; Rinkema \& Williams, 2019; Townsley et al., 2019; Welch, 2019). Most high schools represented in this study were classified as "moderate" or "low" fidelity, meaning that generally some but not all of the teachers were implementing commonly accepted SBL elements. Three of seven students' schools were classified as "moderate" and three other schools were classified as "low" in terms of fidelity.

During the interviews, students were asked questions similar to the initial survey for clarification and confirmability. For example, we asked to what extent students' grades were based on factors other than what they learned in class? Participating students believed that some high school teachers boost the grades of students they like and those who are well-behaved, but this appears to vary from teacher to teacher. This may result from teachers not having a clear understanding of the purposes or practices associated with a standards-based approach. 


\section{Standards-based learning does not appear detrimental to students' transition to higher education.}

When asked to list the three items that were the most difficult parts of their transition to the university, students generally described things unrelated to SBL. In fact, few mentioned any aspect of grading or assessment as one of their major challenges. The most frequently noted transition challenges included: (1) learning to be away from home/friends/family; (2) meeting new friends/getting involved; and (3) time management. Two students mentioned that the university was more academically challenging than they anticipated, but three others said they found it less challenging than anticipated. Although several responses in the initial open-ended survey question described dissatisfaction with retakes and homework not counting toward the academic grade in high school, the interview responses provided a more in-depth description of the college transition.

Overall, students described factors other than SBL as playing a significant role in their transition from high school to the university and discussed SBL issues only when asked. The one student who specifically mentioned SBL as a difficulty in making the transition earned a grade of A in all classes and finished the first university semester with a grade-point average (GPA) of 4.0. Given that the typical GPA of first year students at four-year colleges in the United States is approximately 2.70 (Allen \& Radunzel, 2016), the participants in our study were highly successful in their first semester of academic study at this private Midwestern university. 


\section{Standards-based learning implementation at the high school level is in its infancy.}

The results of this exploratory study indicate that high schools involved in SBL vary widely in their fidelity of implementation and most have only moderate or low levels of implementation. To improve implementation fidelity, school leaders need to initiate serious conversations with staff members about the purpose of SBL and particularly the need to distinguish achievement and non-cognitive factors in determining students' grades (see Guskey, 2020). To ensure consistency among teachers, these conversations need to include discussions about assessment policies and practices, especially how and when students should be provided multiple opportunities to demonstrate their achievement of course learning goals or standards. Embedded in these policies is the need to assist teachers in providing structured opportunities for students to correct any learning errors identified on assessments within the classroom setting (Townsley \& Wear, 2020).

\section{Parent concerns about students' transition from high school to higher education need to be addressed.}

Many factors contribute to students' successful transition to learning in college and university classrooms. The most pressing transition concerns among the students who participated in this study, all who were high achieving students attending a private university with relatively high admission standards, focused primarily on social considerations and time management. Furthermore, these students who graduated from high schools using aspects of standards-based grading were performing as well or better than their university peers. 


\section{Summary and Conclusion}

While all grading systems have both advantages and shortcomings, this study revealed that the implementation of SBL was not detrimental to high school students' transition to university learning environments. Based on these results, school leaders and community members may proceed in their efforts to implement SBL practices free of concern about any negative influence on the success of their students at the post-secondary level.

In addition, other evidence indicates that SBL practices may provide students with notable advantages related to post-secondary transition. An increasing number of post-secondary institutions are relying less on college entrance examination scores in admission decisions and placing more importance on high school grades and grade point averages (Anderson, 2020; Belasco et al., 2015; Rubin \& González, 2019). Admissions officials viewing a standards-based transcript that separates academic achievement grades from important non-cognitive factors may find it more informative because it reveals meaningful information about a variety of factors that contribute to post-secondary success (Guskey, 2020). In addition, college admissions directors confirm that students applying under a standards-based learning system without indicators such as class rank are easily accommodated (Buckmiller \& Peters, 2018; Riede, 2018).

Because typical grading practices combine a "hodgepodge" of factors (Brookhart, 1991), admission officers, students, and parents are unable to discern if a high grade represents a high level of academic achievement, or if it is due to non-cognitive factors such as effort, homework completion, class participation, punctuality in turning in assignments, or extra credit opportunities. Standards-based grading offers a clearer description of students' performance by separating achievement and non-cognitive factors. This allows admission officers, students, and parents to see precisely what concepts and skills that have been learned, as well as what non- 
cognitive elements were displayed. A clearer picture of precisely what high school students have learned and can do also may lessen the need for remedial courses when students transition to higher education (Chen, 2016).

The reassessment opportunities high school teachers offer students in SBL provide opportunities for students to learn from assessments and to take ownership of their learning (Knight \& Cooper, 2019). They also help students learn from their mistakes and act upon instructor feedback (Wiggins, 1998). Indeed, the best preparation for future learning, regardless of the quality of instruction students may encounter in the future, is to learn excellently today (Guskey, 2015; Wormeli, 2017).

The difficulties the students in our study experienced in their transition to the university were generally unrelated to standards-based learning. Based on the evidence gathered from these students, parents can rest assured the degree to which their child's high school is implementing SBL will have no adverse impact on students' transition to a university learning environment.

\section{References}

Adebayo (2008). Cognitive and non-cognitive factors affecting the academic performance and retention of conditionally admitted freshmen. Journal of College Admission, 200, 15- 21.

Allen, J., \& Radunzel, J. (2016). Comparing high school grade point average (GPA) to first-year college GPA. ACT Research \& Policy. Retrieved from http://www.act.org/content/dam/act/unsecured/documents/5840-Data-Byte-2016-10Comparing-High-School-GPA-to-First-Year-College-GPA.pdf

Anderson, N. (2020). Colleges are ditching required admission tests over covid-19. Will they ever go back? Washington Post (June 15). Retrieved from: 
https://www.washingtonpost.com/local/education/coronavirus-sat-actadmission/2020/06/15/18c406dc-acca-11ea-a9d9-a81c1a491c52_story.html

Aspelmeier, J. E., Love, M. M., McGill, L. A., Elliott, A. N., \& Pierce, T. W. (2012). Selfesteem, locus of control, college adjustment, and GPA among first- and continuinggeneration students: A moderator model of generational status. Research in Higher Education, 53(7), 755-781.

Belasco, A. S., Rosinger, K. O., \& Hearn, J. C. (2015). The test-optional movement at America's selective liberal arts colleges: A boon for equity or something else? Educational Evaluation and Policy Analysis, 37(2), 206-223.

Bowen (2018). Students, parents take issue with new grading policy at Rocky Mountain. Meridian Press. Retrieved from https://www.idahopress.com/meridian/news/education/students-parents-take-issue-withnew-grading-policy-at-rocky/article_704acca0-3951-5462-b571-119120bb9d7c.html

Brookhart, S. M. (1991). Grading practices and validity. Educational Measurement: Issues and Practice, 10(1), 35-36.

Buckmiller, T., \& Peters, R. (2018). Getting a fair shot? School Administrator, 75(2), 22-25.

Conley, D. T., \& French, E. M. (2014). Student ownership of learning as a key component of college readiness. American Behavioral Scientist, 58(8), 1018-1034.

Chen, X. (2016). Remedial Coursetaking at U.S. Public 2- and 4-Year Institutions: Scope, experiences, and outcomes (NCES 2016-405). U.S. Department of Education. Washington, DC: National Center for Education Statistics. 
Doyne, S., \& Gonchar, M. (2020). Should schools change how they grade students during the pandemic? New York Times (April 6). Retrieved from: https://www.nytimes.com/2020/04/06/learning/coronavirus-schools-grading.html.

Dueck, M. (2011). How I broke my rule and learned to give retests. Educational Leadership, $69(3), 72-75$.

Farrington, R. (2020). Colleges go to pass-fail due to coronavirus concerns: What does this mean for students. Forbes Magazine, (March 30). Retrieved from: https://www.forbes.com/sites/robertfarrington/2020/03/30/colleges-go-to-pass-fail-due-tocoronavirus-concerns-what-does-this-mean-for-students/\#6e172b8f7eaa.

Frankin, A., Buckmiller, T., \& Kruse, J. (2016). Vocal and vehement: Understanding parents' aversion to standards-based grading. International Journal of Social Science Studies, 4(11), 19-29.

Guskey, T. R. (1994). Making the grade: What benefits students. Educational Leadership, 52(2), $14-20$.

Guskey, T. R. (1996). Reporting on student learning: Lessons from the past - Prescriptions for the future. In T. R. Guskey (Ed.), Communicating Student Learning. 1996 Yearbook of the Association for Supervision and Curriculum Development (pp. 13-24). Alexandria, VA: Association for Supervision and Curriculum Development.

Guskey, T. R. (2014). Class rank weighs down true learning. Kappan, 95(6), 15-19.

Guskey, T. R. (2015). On your mark: Challenging the conventions of grading and reporting. Bloomington, IN: Solution Tree.

Guskey, T. R. (2020). Get set, go! Creating successful grading and reporting systems. Bloomington, IL: Solution Tree. 
Guskey, T. R., \& Bailey, J. M. (2001). Developing grading and reporting systems for student learning. Thousand Oaks, CA: Corwin Press.

Guskey, T. R., \& Bailey, J. M. (2010). Developing standards-based report cards. Thousand Oaks, CA: Corwin Press.

Guskey, T. R., \& Link, L. J. (2019). Exploring the factors teachers consider in determining students' grades. Assessment in Education: Principles, Policy \& Practice, 26(3), 303-320.

Idzerda, C. W. (2018). Standards-based disagreement: Not everybody pleased with grading system. The Gazette. Retrieved from:

https://www.gazettextra.com/news/education/standards-based-disagreement-noteverybody-pleased-with-grading-system/article_a6752bf1-3dcb-5615-8223b3f451401382.html

Knight, M. \& Cooper, R. (2019). Taking on a new grading system: The interconnected effects of standards-based grading on teaching, learning, assessment, and student behavior. NASSP Bulletin, 103(1), 65-92.

Leonard, J. (2013). Maximizing college readiness for all through parental support. School Community Journal, 23(1), 183-200.

Li, J. L., \& McKillip, M. E. (2014). Race variations on the path to college. Journal of College Admission, 223, 24-32

Muñoz, M. A. \& Guskey T.R. (2015). Standards-based grading and reporting will improve education. Phi Delta Kappan, 96(7), 64-68.

Murray, C. (2019). Parents oppose standards-based grading system. $K C P W$. Retrieved from https://www.kpcw.org/post/parents-oppose-standards-based-grading-system\#stream/0 
O’Connor, K. (2017). A case for standards-based grading and reporting. School Administrator, 74(1), 24-28.

O’Connor, K. (2018). How to grade for learning (4th ed.). Corwin.

Reynolds, A. L., \& Weigand, M. J. (2010). The relationships among academic attitudes, psychological attitudes, and the first-semester academic achievement of first-year college students. Journal of Student Affairs Research and Practice, 47(2), 175-195.

Reynolds, L., Fisher, D., \& Cavil, J. K. (2012). Impact of demographic variables on AfricanAmerican student athletes' academic performance. Educational Foundations, 26(3/4), 93111.

Riede, P. (2018). Making the call inside admissions offices. School Administrator, 75(2), 26-29.

Rinkema, E., \& Williams, S. (2019). The standards-based classroom: Make learning the goal. Thousand Oaks, CA: Corwin.

Rubin, P. G., \& González Canché, M. S. (2019). Test-flexible admissions policies and student enrollment demographics: Examining a public research university. The Review of Higher Education, 42(4), 1337-1371.

Schimmer, T., Hillman, G., \& Stalets, M. (2018). Standards-based learning in action: Moving from theory to practice. Solution Tree.

Sommerfeld, A. (2011). Recasting non-cognitive factors in college readiness as what they truly are: Non-academic factors. Journal of College Admission, 213, 18-22.

St. George, D. (2020). Letter grades get erased from school, with little consensus on how to replace them. The Washington Post (April 26). Retrieved from: https://www.washingtonpost.com/local/education/montgomery-county-gradescoronavirus/2020/04/25/7bbfd8ce-7b3d-11ea-b6ff-597f170df8f8_story.html. 
Svrluga, S. (2020). Colleges are ditching letter grades this spring, but not all students are on board with 'ungrading.' The Washington Post, (April 6). Retrieved from: https://www.washingtonpost.com/education/2020/04/06/college-grading-coronavirus/.

Tellers, J. (2017). Grade scale change raises concern. Retrieved from: http://www.dailyjournal.net/2017/03/16/uproar_over_clark_pleasant_grade_system/

Ting, S. R. (1998). Predicting first-year grades and academic progress of college students of first-generation and low-income families. Journal of College Admission, 158, 14-23.

Ting, S. R. (2009). Impact of non-cognitive factors on first-year academic performance and persistence of NCAA division I student athletes. Journal of Humanistic Counseling, Education and Development, 48(2), 215-228.

Ting, S. R., \& Robinson, T. L. (1998). First-year academic success: A prediction combining cognitive and psychosocial variables for Caucasian and African-American students. Journal of College Student Development, 39(6), 599-610.

Townsley, M. (2019). Considering standards-based grading: Challenges for school leaders. Journal of School Administration Research and Development, 4(1), 35-38.

Townsley, M., Buckmiller, T., \& Cooper, R. (2019). Anticipating a second wave of standardsbased grading implementation and understanding the potential barriers: Perceptions of high school principals. NASSP Bulletin, 103(4), 281-299.

Townsley, M., \& Wear, N. (2020). Making grades matter: Standards-based grading in a secondary PLC at work. Bloomington, IN: Solution Tree.

Tracey, T. J., \& Sedlaceck, W. E. (1984). Non-cognitive variables in predicting academic success by race. Measurement and Evaluation in Guidance, 16(4), 171-178. 
Welch, M. (2019). Standards-based grading. In T. R. Guskey and S. M. Brookhart (Eds.), What do we know about grading: What works, what doesn't, and what's next (pp. 113-144). Alexandria, VA: Association for Supervision and Curriculum Development.

Wiggins, G. (1998). Educative assessment: Designing assessment to inform and improve student performance. San Francisco, CA: Jossey-Bass.

Wormeli, R. (2011). Redos and retakes done right. Educational Leadership, 69(3), 22-26.

Wormeli, R. (2017). We have to prepare students for the next level, don't we? AMLE Magazine, $5(1), 31-33$. 